\title{
Cell cycle progression and apoptosis after irradiation in an acidic environment
}

\author{
HJ Park ${ }^{\star, 1,2}$, JC Lyons ${ }^{1}$, T Ohtsubo ${ }^{1}$ and CW Song ${ }^{1}$ \\ ${ }^{1}$ University of Minnesota Medical School, Department of Therapeutic \\ Radiology-Radiation Oncology, Radiation Biology Section, 420 Delaware St. \\ S.E., Box 494 Mayo, Minneapolis, MN 55455, USA \\ 2 Inha University, College of Medicine, Department of Microbiology, \\ 253 Yong-Hyun Dong, Nam-Gu, Inchon 402-751, Korea \\ * Corresponding author: HJ Park, Department of Therapeutic Radiology- \\ Radiation Oncology, University of Minnesota Medical School, 420 Delaware St. \\ S.E., Box 494 Mayo, Minneapolis, MN 55455, USA. Tel: (612) 626-6090; \\ Fax: (612) 626-6245; E-mail: chaex001@tc.umn.edu
}

Received 22.7.99; revised 15.12.99; accepted 28.3.00

Edited by DR Green

\begin{abstract}
We investigated the effect of an acidic environment on the radiation-induced G2/M arrest and apoptosis using RKO.C human colorectal cancer cells expressing wild-type p53 and RC10.1 cells, a subline of RKO.C cells deficient in p 53 as well as

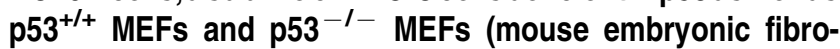
blasts). The cells were irradiated with 4 Gy or 12 Gy of $\gamma$-rays in pH 7.5 medium or pH 6.6 medium. p53 accentuated the progression of cells from radiation-induced G2/M arrest to apoptosis and the $\mathrm{pH} 6.6$ environment suppressed the progression of cells through G2/M-phase to apoptosis after irradiation. Further analysis indicated that the radiationinduced G2/M arrest was due mainly to $\mathrm{G} 2$ arrest in both $\mathrm{pH} 7.5$ and pH 6.6. Therefore, it was concluded that $p 53$ enhances, and an acidic environment suppresses, the exit of cells from radiation-induced $\mathrm{G} 2$ arrest by altering cyclin $\mathrm{B} 1-\mathrm{Cdc} 2$ kinase activity. Cell Death and Differentiation (2000) 7, 729-738.
\end{abstract}

Keywords: apoptosis; p53; G2/M arrest; cyclin B1-Cdc2 kinase; acidic environment

Abbreviations: Cdc2 kinase, cyclin-dependent serine/threonine protein kinase; PARP, poly(ADP-ribose) polymerase; PI, propidium iodide; SDS-PAGE, sodium dodecyl sulfate-poly acrylamide gel electrophoresis

\section{Introduction}

It is a well-known fact that the interstitial environment in human tumors is acidic relative to that in normal tissues. ${ }^{1-4}$ It would be reasonable to expect that such an acidic intratumor environment greatly affects various metabolic processes and proliferation of tumor cells as well as the response of tumor cells to various therapeutic insults. In fact, an acidic environment alone has been demonstrated to kill tumor cells by apoptosis, ${ }^{5,6}$ enhance the response of tumor cells to many chemotherapy drugs,,$^{7,8}$ and hyperthermia. ${ }^{9-12}$ On the other hand, an acidic environment has been reported to increase radioresistance of tumor cells. ${ }^{12}$ We have found that an acidic environment suppresses the exit of cells from radiationinduced G2/M arrest, thereby suppressing radiation-induced apoptosis in SCK mouse tumor cells ${ }^{13}$ and also in HL-60 human leukemia cells. ${ }^{14}$ It is well established that the tumor suppressor gene p53 is intimately involved in cell cycle progression and apoptosis in irradiated cells. ${ }^{15,16}$ Since the p53 in SCK cells is mutated, and HL-60 cells are deficient in p53, the role of p53 in the aforementioned effect of an acidic environment on the transition of irradiated cells through G2/Mphase to apoptosis has been unclear.

It has been reported that various cells carrying wild-type p53 are arrested in G1 phase after DNA damage due to transcriptional upregulation of $\mathrm{p} 21^{\mathrm{WAF} 1 / \mathrm{CIP} 1}$, which inhibits the kinases involved in cell cycle progression. ${ }^{16-18}$ However, indications are that such a relationship is not absolute between the upregulation of p53 and G1 arrest, particularly in tumor cells. ${ }^{19-22}$ It has also been reported that G2/M arrest occurs after DNA damage, regardless of the status of p53, suggesting that p53 is not required for G2/M arrest. $^{16,23-28}$ On the other hand, it has become increasingly evident during the last several years that the exit of cells from G2/M arrest after DNA damage is influenced by p53. Bunz et $a l^{29}$ reported that p53 inhibited the exit of $G 2$ cells to mitosis in various human cancer and normal cells after irradiation with $12 \mathrm{~Gy}$. In apparent contradiction to this report, other investigators have reported that p53 accelerated the exit of cells from G2 arrest to mitosis and apoptosis after DNA damage. ${ }^{28,30-33}$ In the present study, we investigated the kinetics of G2/M arrest and apoptosis after irradiation in different $\mathrm{pH}$ environments using RKO.C human colorectal cancer cells carrying wild-type p53 and E6transfected RC10.1 cells and mouse embryonic fibroblast MEFs with or without p53. The relationship between the G2/ $\mathrm{M}$ arrest and cyclin B1-Cdc2 kinase activity in the different $\mathrm{pH}$ environments was also investigated.

\section{Results \\ Cell cycle progression and apoptosis after irradiation in RKO.C cells and RC10.1 cells}

Figure 1 shows the histogram of DNA contents or cell cycle distribution in RKO.C cells and RC10.1 cells, as determined with propidium iodide $(\mathrm{PI}) /$ flow cytometry after irradiation with $12 \mathrm{~Gy}$ in $\mathrm{pH} 7.5$ medium and $\mathrm{pH} 6.6$ medium. The per cent of cells in G2/M-phase at varying times after irradiation was obtained from the histograms and is shown in Table 1. Figure $1 \mathrm{~A}$ shows that the rate of accumulation of irradiated RKO.C cells in G2/M-phase was slightly slower in $\mathrm{pH} 6.6$ medium as compared to that in $\mathrm{pH} 7.5$ medium. As shown in Table 1, about $70 \%$ of RKO.C cells accumulated in G2/M-phase 16$24 \mathrm{~h}$ after 12 Gy irradiation in $\mathrm{pH} 7.5$ medium, whereas about 
$50 \%$ of the cells accumulated in G2/M-phase during the same period after irradiation in $\mathrm{pH} 6.6$ medium. The exit of irradiated RKO.C cells from G2/M arrest to apoptosis was also markedly delayed in $\mathrm{pH} 6.6$ medium relative to that in $\mathrm{pH} 7.5$ medium. Consequently, about $36 \%$ of the cells in $\mathrm{pH} 6.6$ medium were still in G2/M-phase $72 \mathrm{~h}$ after irradiation whereas only $8 \%$ of cells were in G2/M-phase in $\mathrm{pH} 7.5$ medium at the same time. A similar effect of an acidic environment on cell cycle progression, including accumulation in G2/M-phase and subsequent apoptosis, was observed in RC10.1 cells after 12 Gy irradiation (Figure 1B). When RC10.1 cells were irradiated with $12 \mathrm{~Gy}$ and maintained in $\mathrm{pH} 7.5$ medium, $76 \%$ of the cells accumulated in G2/M-phase by $24 \mathrm{~h}$. Thereafter, the cells began to exit from G2/M arrest and only

(A) RKO.C

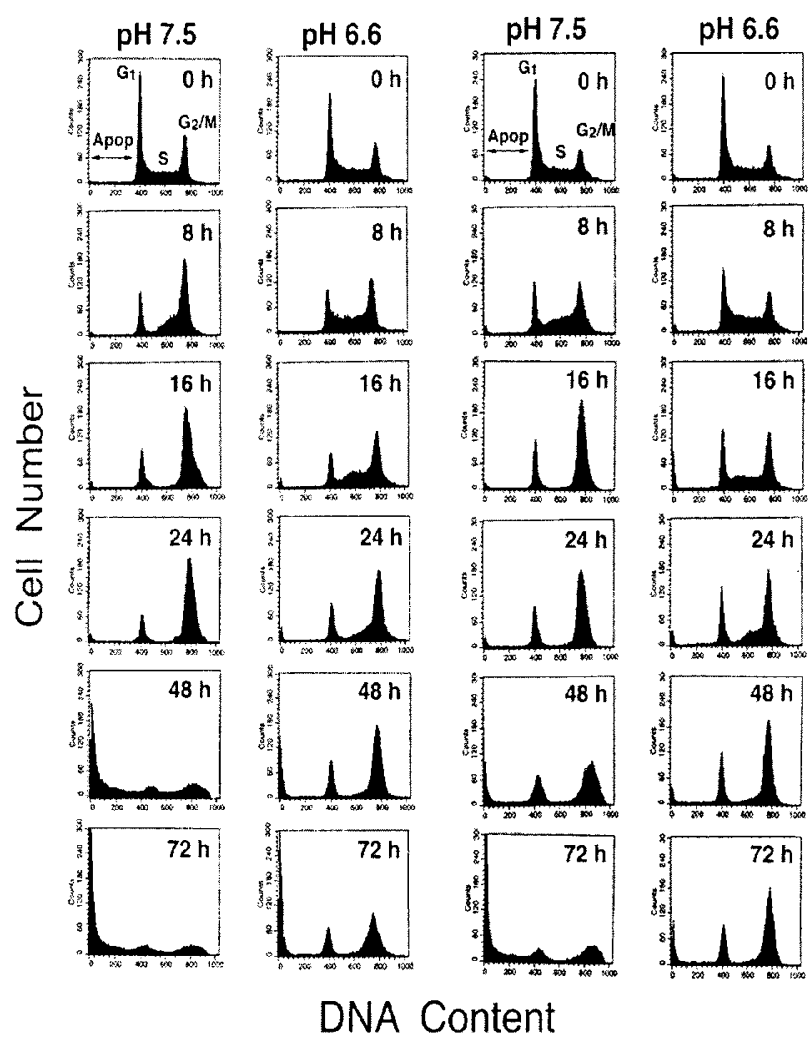

Figure 1 A typical example of cell cycle progression of RKO.C cells. (A) and RC10.1 cells (B) determined with the propidium iodide/flow cytometry method, after a 12 Gy irradiation and incubation in $\mathrm{pH} 7.5$ or pH 6.6 media

Table 1 Percentage of cells in G2/M-phase at different times after 12 Gy irradiation

\begin{tabular}{lcccc}
\hline & \multicolumn{2}{c}{ RKO.C } & \multicolumn{2}{c}{ RC10.1 } \\
Hours & pH 7.5 & pH 6.6 & pH 7.5 & pH 6.6 \\
\hline 0 & $27.2 \pm 1.7$ & $30.2 \pm 2.2$ & $23.9 \pm 2.3$ & $25.0 \pm 2.3$ \\
4 & $31.5 \pm 1.9$ & $31.1 \pm 4.4$ & $29.9 \pm 3.4$ & $26.2 \pm 2.5$ \\
8 & $51.6 \pm 3.0$ & $42.6 \pm 1.3$ & $45.7 \pm 3.5$ & $30.8 \pm 2.7$ \\
16 & $69.3 \pm 6.0$ & $52.5 \pm 2.9$ & $51.5 \pm 2.9$ & $47.2 \pm 3.2$ \\
24 & $70.2 \pm 6.6$ & $51.0 \pm 3.9$ & $75.7 \pm 1.9$ & $59.4 \pm 4.2$ \\
48 & $20.5 \pm 4.5$ & $45.7 \pm 5.0$ & $44.3 \pm 0.9$ & $60.0 \pm 3.0$ \\
72 & $7.5 \pm 3.0$ & $36.3 \pm 7.8$ & $15.7 \pm 3.3$ & $44.6 \pm 6.7$ \\
\hline
\end{tabular}

about $16 \%$ of cells were in G2/M phase by $72 \mathrm{~h}$. On the other hand, in $\mathrm{pH} 6.6$ medium, the percentage of RC10.1 cells in G2/M-phase gradually increased to $60 \%$ by $48 \mathrm{~h}$ after irradiation and then slowly declined to $45 \%$ by $72 \mathrm{~h}$.

A comparison of Figure $1 \mathrm{~A}$ and $\mathrm{B}$ indicates that the per cent of accumulated RKO.1 cells in G2/M-phase after irradiation was similar to that in R10.1 cells in the same $\mathrm{pH}$ medium.

However, RKO.C cells exited from G2/M arrest faster than $\mathrm{RC} 10.1$ cells in $\mathrm{pH} 7.5$ medium. For example, $70 \%$ of RKO.C cells in $\mathrm{pH} 7.5$ medium were in G2/M-phase $24 \mathrm{~h}$ after 12 Gy irradiation, and the percentage of cells in G2/Mphase decreased to $20 \%$ by $48 \mathrm{~h}$, whereas $76 \%$ of $\mathrm{RC} 10 \cdot 1$ cells were in G2/M-phase $24 \mathrm{~h}$ after $12 \mathrm{~Gy}$ irradiation in $\mathrm{pH}$ 7.5 medium and they decreased to $44 \%$ by $48 \mathrm{~h}$ (Table 1 ). Unlike the cells in $\mathrm{pH} 7.5$ medium, the rate to exit from radiation-induced G2/M arrest in $\mathrm{RKO} \cdot 1$ cells in $\mathrm{pH}$ 6.6. medium was similar to that in RC10.1 cells. Figure 2 shows the increase in apoptotic cell population after $12 \mathrm{~Gy}$ irradiation, as determined from the DNA histogram (Figure 1). It is clear that the post-mitotic apoptosis occurred faster in RKO.C cells than in RC10.1 cells more markedly in 7.5 medium than in $\mathrm{pH} 6.6$ medium after irradiation.

Figure 3 shows the cell cycle distribution at $24 \mathrm{~h}$ after 4 Gy irradiation in RKO.C cells and RC10.1 cells as determined with $\mathrm{Pl} /$ flow cytometry method. When RKO.C cells were irradiated with $4 \mathrm{~Gy}$ in $\mathrm{pH} 7.5$ medium, the G2/M arrest peaked at $16 \mathrm{~h}$ and then apoptosis began to appear, resulting in about 15\% of the cells apoptosing by $24 \mathrm{~h}$. When $\mathrm{RC} 10.1$ cells were irradiated with $4 \mathrm{~Gy}$ in $\mathrm{pH} 7.5$ medium, G2/M arrest also peaked at $16 \mathrm{~h}$, but unlike in the RKO.C cells, the majority of the irradiated RC10.1 cells remained in the G2/M-phase and little apoptosis occurred by $24 \mathrm{~h}$. In $\mathrm{pH} 6.6$ medium there was no evidence of apoptosis $24 \mathrm{~h}$ after $4 \mathrm{~Gy}$ irradiation in both RKO.C cells

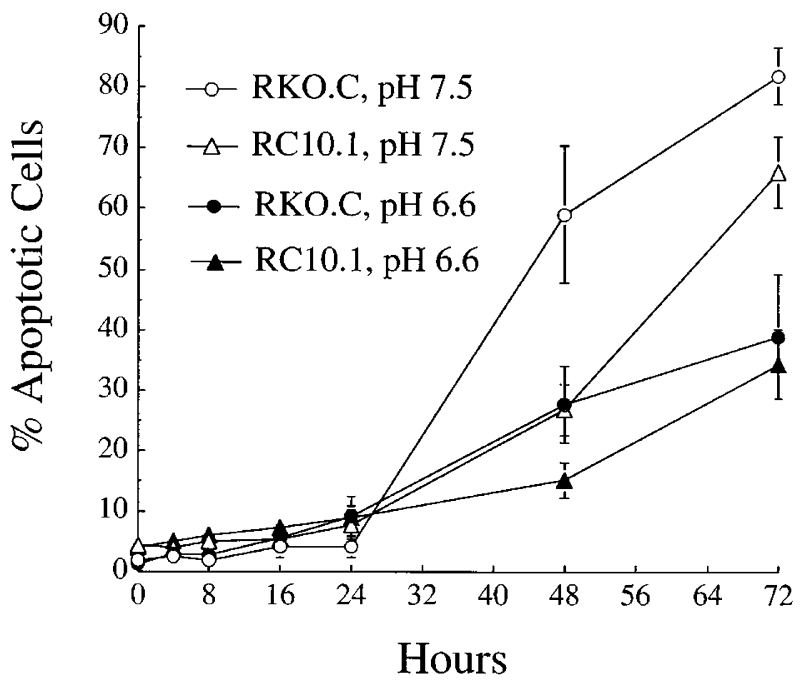

Figure 2 Changes in percentage of RKO.C or RC10.1 cells in apoptosis as a function of time after a $12 \mathrm{~Gy}$ irradiation in $\mathrm{pH} 7.5$ or $\mathrm{pH} 6.6$ media. The cells with sub- $\mathrm{G}_{1}$ DNA content in the flow cytometric analysis shown in Figure 1 were judged as apoptotic cells. Means of 3-5 experiments with quadruplet samples and 1 S.E. are shown 

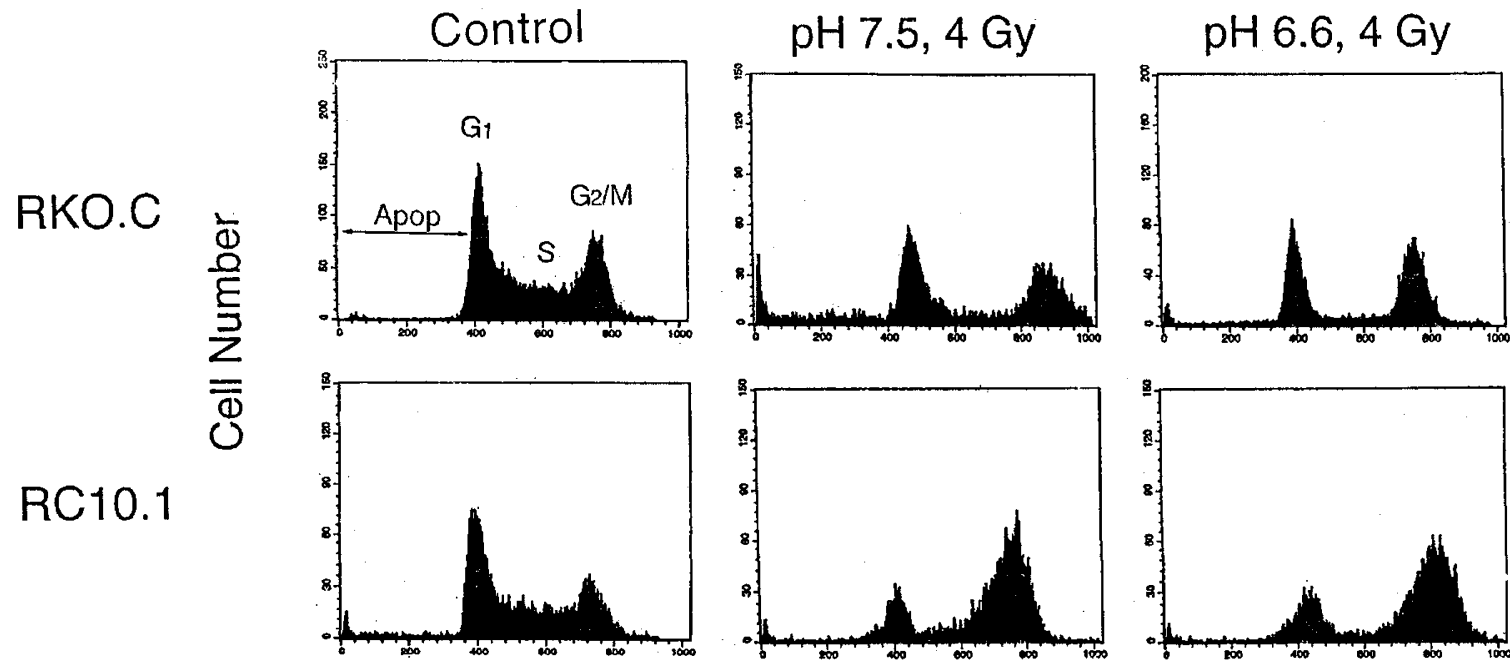

DNA Content

Figure 3 Cell cycle distribution of RKO.C cells and RC10.1 cells, determined with propidium iodide/flow cytometry method, $24 \mathrm{~h}$ after irradiation with $4 \mathrm{~Gy}$ in $\mathrm{pH} 7.5$ or $\mathrm{pH} 6.6$ media

and $\mathrm{RC} 10.1$ cells. These preliminary results clearly indicated that RKO.C cells were faster than RC10.1 cells to exit from the G2/M arrest caused by 4 Gy irradiation in $\mathrm{pH} 7.5$ medium, and that the $\mathrm{pH} 6.6$ environment suppressed the progression of $\mathrm{G} 2 / \mathrm{M}$ cells to $\mathrm{G} 1$ phase or apoptosis in both RKO.C cells and RC10.1 cells, which are findings similar to those after $12 \mathrm{~Gy}$ irradiation. Detailed studies on the effects of $4 \mathrm{~Gy}$ irradiation on the cell cycle progression and apoptosis are in progress in our laboratory.

\section{Cell cycle progression and apoptosis after irradiation in $\mathrm{p}^{2} 3^{+/+}$and $\mathrm{p} 53^{-/-}$MEFs}

Using the $\mathrm{Pl} /$ flow cytometry method, we investigated the G2/M arrest and subsequent apoptosis in MEFs after irradiation in $\mathrm{pH}$ 7.5 and pH 6.6 media. The effects of p53 status and pH on the rate of increase in G2/M cells and on the rate of exit from G2/M arrest after irradiation in MEFs were similar to those in RKO.C cells and RC10.1 cells. In brief, the radiation-induced G2/M arrest in $\mathrm{p} 53^{+/+}$MEFs was shorter than that in $\mathrm{p} 53^{-/-}$MEFs in both $\mathrm{pH} 7.5$ and $\mathrm{pH} 6.6$ media, and an acidic environment

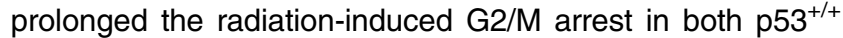
MEFs and $\mathrm{p} 53^{-1-}$ MEFs (data not shown). These changes in the kinetics of G2/M arrest resulted in changes in the kinetics of apoptosis. Figure 4 shows that after 4 Gy irradiation $\mathrm{p} 53^{+/+}$ MEFs apoptosed much faster than $053^{-1-}$ MEFs in both $\mathrm{pH}$ 7.5 and $\mathrm{pH} 6.6$ media and that the radiation-induced apoptosis in $\mathrm{pH} 7.5$ medium was faster than that in $\mathrm{pH} 6.6$ medium. The slight decline in per cent of apoptosis in $\mathrm{pH} 7.5$ medium from $48 \mathrm{~h}$ after irradiation may be due to disintegration of cells which apoptosed before $48 \mathrm{~h}$ after irradiation.

\section{Analysis of $\mathbf{G 2}$ cells and M cells}

In the cell cycle analysis using Pl/flow cytometry, as shown in Figures 1 and 3, G2 and M cells were indistinguishable.

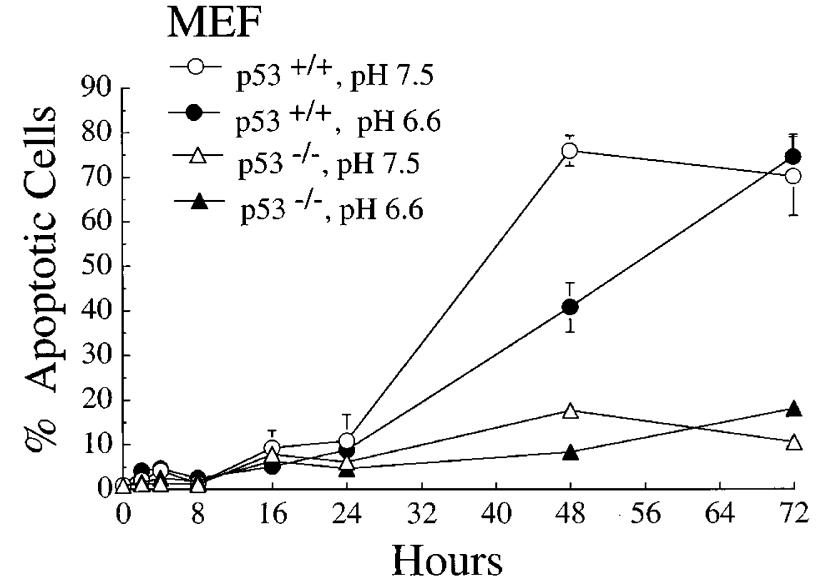

Figure 4 Changes in percentage of $\mathrm{p}^{+/+}$and $\mathrm{p} 53^{-1-}$ MEFs in apoptosis as a function of time after $4 \mathrm{~Gy}$ irradiation in $\mathrm{pH} 7.5$ or $\mathrm{pH} 6.6$ media. The cells with sub-G1 DNA content in the flow cytometric analysis of DNA content were judged as apoptotic cells. Means of 3-5 experiments with quadruplet samples and 1 S.E. are shown

Therefore, it was impossible to know whether the prolongation of radiation-induced G2/M arrest in the cells deficient in p53 or that in acidic medium was due to arrest of cells in G2 phase or M-phase. This question was addressed using the acridine orange/flow cytometry method. ${ }^{34}$ First, we conducted a control study in which cell cycle distribution was determined after cells were treated with colcemide, which arrests cells in mitosis. When RKO.C cells were treated with colcemid, nearly $30 \%$ of the cells already had accumulated in M-phase in $4 \mathrm{~h}$ (Figure 5). This study demonstrated that the acridine orange/ flow cytometry method is capable of distinguishing $M$ cells from $\mathrm{G} 1, \mathrm{~S}$ and $\mathrm{G} 2$ cells. Figure 6 shows that after exposing RKO.C or RC10.1 cells to 12 Gy either in $\mathrm{pH} 7.5$ medium or 


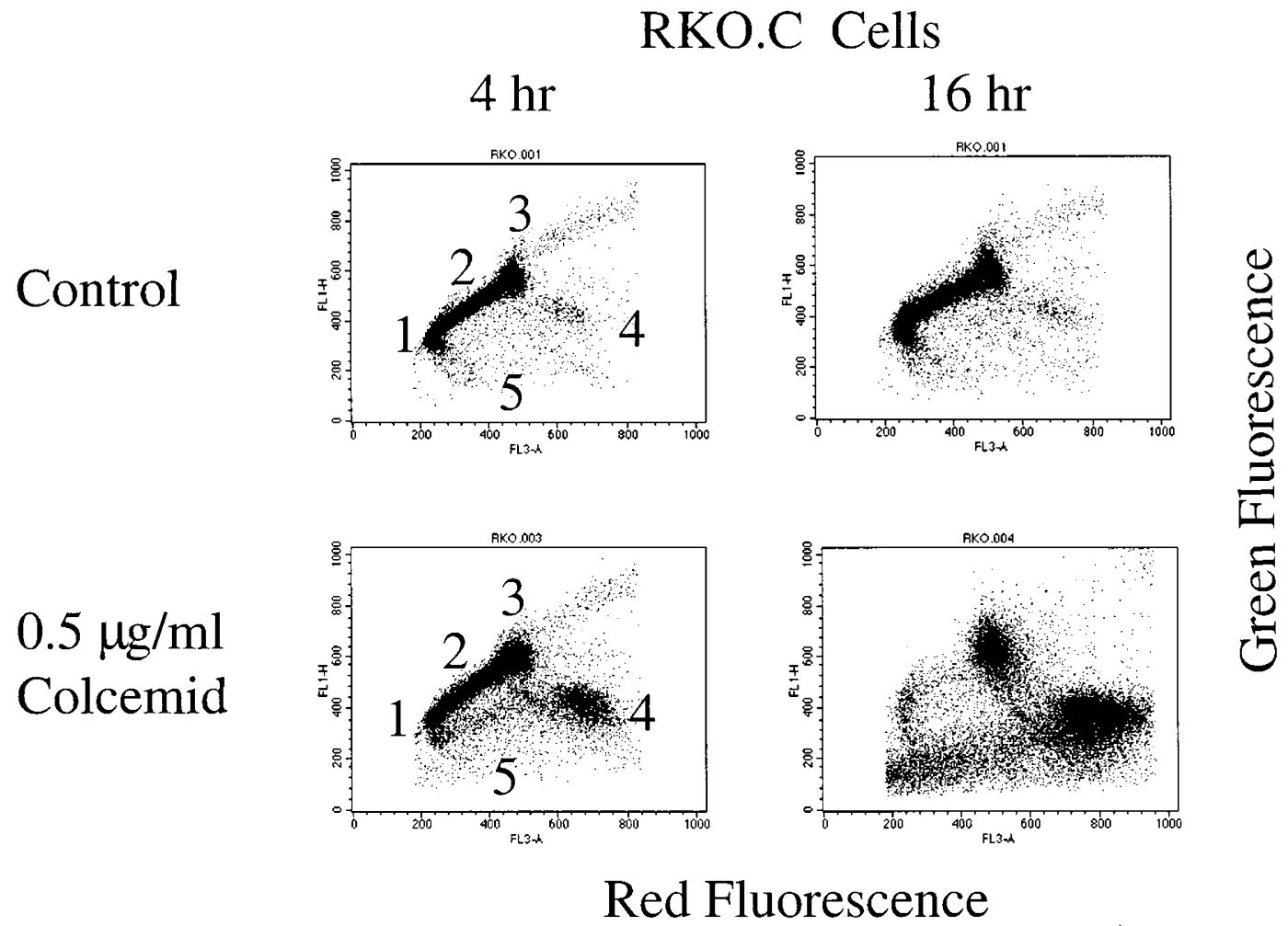

Figure 5 Flow cytometric determination of cell cycle distribution of RKO.C cells stained with acridine orange after treatment with $0.5 \mu \mathrm{g} / \mathrm{ml}$ of colcemid. Distribution of cells with respect to green luminescence (double-stranded DNA) versus red luminescence (single-stranded DNA, i.e. mitotic cells) is shown. The DNA of mitotic cells (4) are most sensitive to acid-induced denaturation and thus are distinguished by high red and low green luminescence with respect G1 cells (1), S cell (2) and G2 cells (3). The cells in early apoptosis are clustered in region (5)

$\mathrm{pH} 6.6$ medium, the G2 cell population increased until $48 \mathrm{~h}$ without any sign of a significant increase in the accumulation of cells in M-phase, although there were small increases in M cells population $72 \mathrm{~h}$ after irradiation. Therefore, it could be concluded that the increase in G2/M cell population after irradiation, which was observed with the $\mathrm{Pl} /$ flow cytometry method (Figures 1 and 3), was due mainly to $\mathrm{G} 2$ arrest in $\mathrm{pH}$ 7.5 and pH 6.6 media in both RKO and R10.1 cells. Thus it would follow that the longer G2/M arrest in RC10.1 cells as compared to that in RKO.C cells after irradiation was due to prolongation of $\mathrm{G} 2$ arrest rather than prolongation of $\mathrm{M}$ arrest. Likewise, the prolonged G2/M arrest in RKO.C cells after irradiation in $\mathrm{pH} 6.6$ medium compared to that in $\mathrm{pH} 7.5$ medium (Figures 1 and 3) may be attributed to prolongation of $\mathrm{G} 2$ arrest after irradiation in $\mathrm{pH} 6.6$ medium.

\section{PARP cleavage and DNA fragmentation}

Cleavage of PARP to an $85 \mathrm{KD}$ fragment by caspases and degradation of DNA to oligonucleosomal fragments are common features of apoptosis. ${ }^{35}$ Figure 7 shows the PARP cleavage and DNA fragmentation in RKO.C and RC10.1 cells $48 \mathrm{~h}$ after $12 \mathrm{~Gy}$ irradiation in $\mathrm{pH} 7.5$ medium or $\mathrm{pH} 6.6$ medium. In the RKO.C cells, there was marked PARP cleavage and DNA fragmentation in $\mathrm{pH} 7.5$ medium but not in $\mathrm{pH} 6.6$ medium. In RC10.1 cells, there was slight PARP cleavage and DNA fragmentation at $48 \mathrm{~h}$ after irradiation in
$\mathrm{pH} 7.5$ medium but not in $\mathrm{pH} 6.6$ medium. These results are in good agreement with the results of the flow cytometry study (Figures 1, 2 and 3) that more apoptosis occurred in RKO.C cells than in RC10.1 cells in pH 7.5 medium by $48 \mathrm{~h}$ after irradiation and that only a small fraction of cells underwent apoptosis by $48 \mathrm{~h}$ after 12 Gy irradiation in both RKO.C cells and $\mathrm{RC} 10.1$ cells in $\mathrm{pH} 6.6$ medium.

\section{p53 and p21 proteins}

The changes in levels of $p 53$ and p21 proteins in RKO.C cells and $\mathrm{RC} 10.1$ cells after 12 Gy irradiation in $\mathrm{pH} 7.5$ medium and pH 6.6 medium are shown in Figure 8. In the RKO.C cells irradiated in $\mathrm{pH} 7.5$ medium, the level of p53 markedly increased within $2 \mathrm{~h}$ and peaked at $4 \mathrm{~h}$. Although the p53 level slightly declined thereafter, it was still significantly higher than that in the unirradiated control cells at $72 \mathrm{~h}$ after irradiation. In pH 6.6 medium, the p53 level in RKO.C cells increased until $8 \mathrm{~h}$ after irradition and then gradually decreased. Note that the peak increase in p53 level in RKO.C cells occurred at $4 \mathrm{~h}$ in $\mathrm{pH} 7.5$ medium while it occurred at $8 \mathrm{~h}$ in $\mathrm{pH} 6.6$ medium after 12 Gy irradiation.

The p21 level in RKO.C cells in pH 7.5 medium slightly increased by $2 \mathrm{~h}$ and continued to increase and peaked at $48 \mathrm{~h}$ after irradiation. In pH 6.6 medium, the p21 level in RKO.C cells slightly increased by $4 \mathrm{~h}$ and peaked at $24-$ $48 \mathrm{~h}$ after irradiation. The level of p21 in pH 6.6 medium 
RKO.C

Control
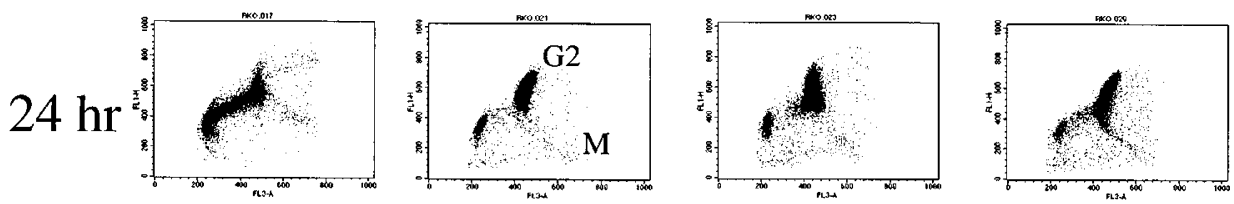

pH 7.5

$\mathrm{RC} 10.1$

pH 6.6
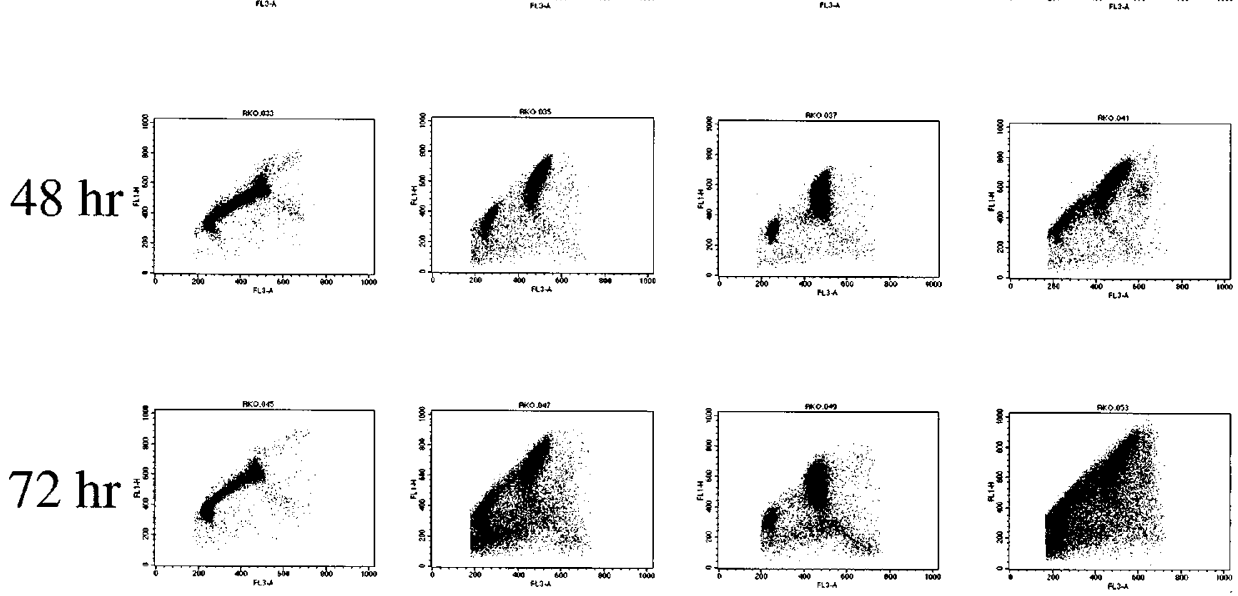
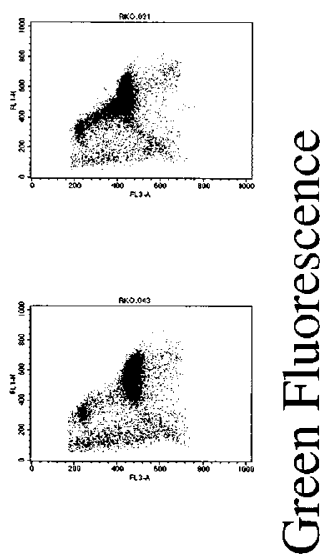

\section{Red Fluorescence}

Figure 6 Flow cytometric determination of cell cycle distribution of RKO.C cells and RC10.1 cells after irradiation with $12 \mathrm{~Gy}$ in pH 7.5 or pH 6.6 media. The DNA of the cells was denatured with acid and stained with acridine orange. The distribution of the cells with respect to their red and green luminescence are shown (see the legend for Figure 5)

RKO.C

RC10.1

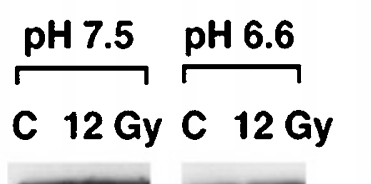

97.4-
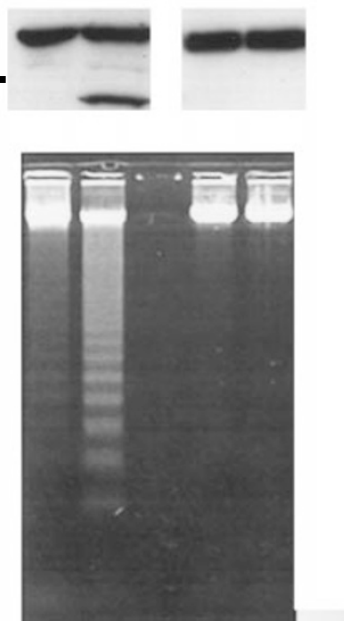

pH $7.5 \stackrel{\mathrm{pH} 6.6}{\longrightarrow}$
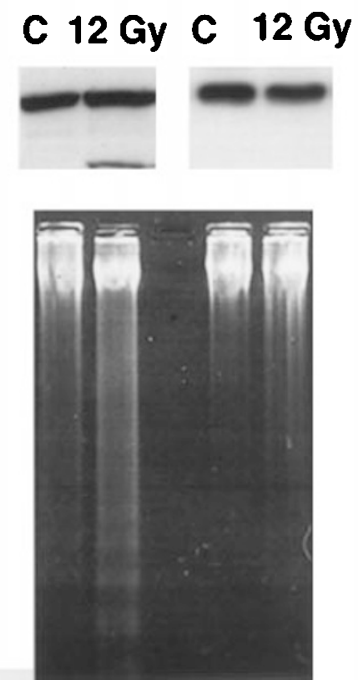

Figure 7 Radiation-induced cleavage of PARP and DNA fragmentation in RKO.C cells or RC 10.1 cells at $48 \mathrm{~h}$ after 12 Gy irradiation. Radiation induced PARP cleavage was seen in cells in pH 7.5 medium but not in pH 6.6 medium in both cell lines was far less than that in $\mathrm{pH} 7.5$ medium at all times after irradiation. As expected, the levels of p53 and p21 in RC10.1 cells were negligible before and after irradiation with 12 Gy in both $\mathrm{pH} 7.5$ and $\mathrm{pH} 6.6$ media. The changes in p53 and p21 protein levels after 4 Gy irradiation were qualitatively the same as those by 12 Gy irradiation in both $\mathrm{pH} 7.5$ and $\mathrm{pH} 6.6$ media (data not shown).

\section{Cyclin B1-Cdc2 kinase activity}

In the RKO.C cells and RC10.1 cells irradiated in $\mathrm{pH} 7.5$ medium, the kinase activity of cyclin B1-Cdc2 complex significantly decreased during the first 4-8 h after irradiation and then began to recover (Figure 9). In the RKO.C cells, the kinase activity recovered by $16 \mathrm{~h}$, peaked at $24 \mathrm{~h}$, and then decreased. In the RC10.1 cells, the kinase activity recovered by $24 \mathrm{~h}$, continuously increased until $48 \mathrm{~h}$, and then slightly declined at $72 \mathrm{~h}$ after irradiation. Note that at $48 \mathrm{~h}$ after irradiation, the kinase activity in the RKO.C cells was almost the same as that in the control cells, whereas that the kinase activity in the RC10.1 cells at $48 \mathrm{~h}$ after irradiation was twofold that in the control cells. The change in cyclin B1-Cdc2 kinase activity in $\mathrm{pH} 6.6$ medium was similar to that in both cell lines in $\mathrm{pH} 7.5$ medium until $24 \mathrm{~h}$ after irradiation; the kinase activity initially declined and then progressively increased until $24 \mathrm{~h}$. Interestingly, the kinase activity in the cells in $\mathrm{pH} 6.6$ medium 


\section{RKO.C}

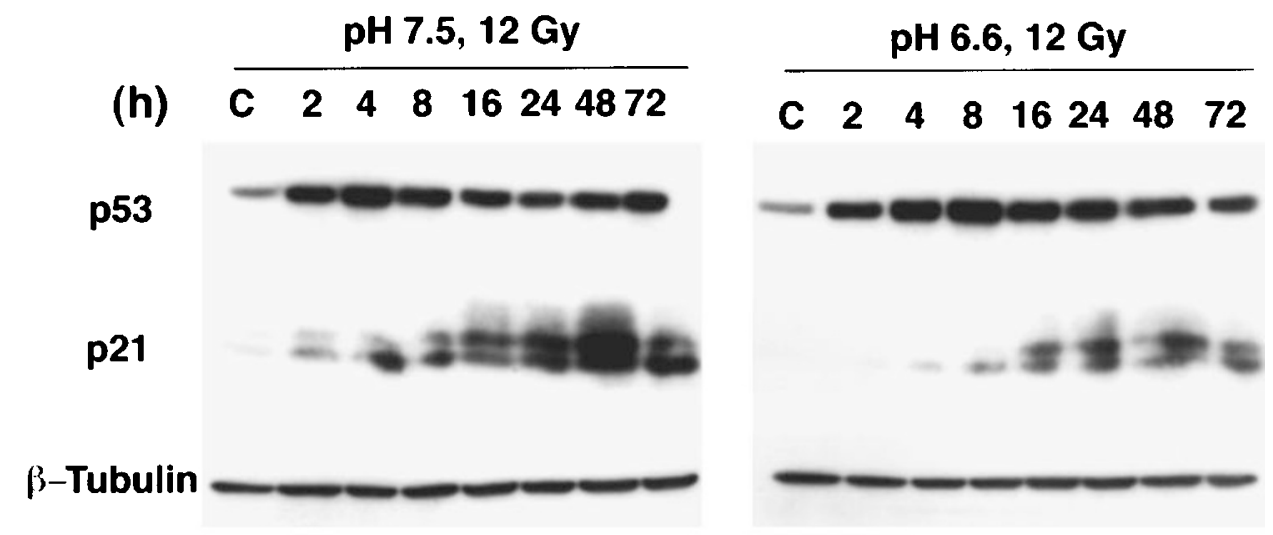

RC10.1

pH 7.5, 12 Gy

(h) $\begin{array}{llllllll}\text { C } & 2 & 4 & 8 & 16 & 24 & 48 & 72\end{array}$
pH 6.6, 12 Gy

\begin{tabular}{lllll}
\hline C 2448 & 8 & 164842
\end{tabular}

p53

p21

\section{B-Tubulin}

Figure 8 Immunoblot analysis of p53, p21, and $\beta$-Tubulin expression in RKO.C cells and RC10.1 cells after a 12 Gy irradiation in pH 7.5 or pH 6.6 media

abruptly decreased after the peak increase at $24 \mathrm{~h}$, more so in the RKO.C cells than in the RC10.1 cells. Consequently, the kinase activity in the RKO.C cells $48-72 \mathrm{~h}$ after irradiation in $\mathrm{pH} 6.6$ medium was markedly less than that in the control cells.

\section{Discussion}

The results obtained with the flow cytometry method, DNA fragmentation and PARP cleavage demonstrated that p53 accelerates the progression of irradiated tumor cells through G2 phase thereby facilitating the appearance of post-mitotic apoptosis. The present study also demonstrated that an acidic environment suppresses progression of irradiated cells through G2 phase thereby suppressing the occurrence of post-mitotic apoptosis, regardless of the p53 status of cells. The variation in progression of cells through G2/M-phase after irradiation due to differences in p53 status and/or environmental $\mathrm{pH}$ could be attributed to a variance in cyclin-B-Cdc2 kinase activity.

It has been reported that G2/M arrest occurs when DNA is damaged by ionizing irradiation regardless of p53 status suggesting that activation of G2/M checkpoint is independent of p53 status. ${ }^{16,23-28}$ In agreement with these reports, both p53-positive RKO.C cells and p53-deficient RC10.1 cells arrested in G2/M-phase after irradiation in $\mathrm{pH} 7.5$ environment in the present study (Figures 1 and 3), although the rate of accumulation in G2/M-phase after irradiation was slightly slower in RC10.1 cells as compared to the RKO.C cells. However, the G2/M arrest caused by a 4 or 12 Gy irradiation decayed significantly faster in RKO.C cells than in RC10.1 cells in $\mathrm{pH} 7.5$ environment. Consequently, the rate of appearance of apoptosis which followed the G2/M arrest was faster in RKO.C cells as compared to that in RC10.1 cells (Figure 2). We also observed that $\mathrm{p} 53^{+/+}$MEFs apoptosed faster than $\mathrm{p} 53^{-/-}$ MEFs after 4 Gy irradiation (Figure 4). In fact, the role of 
A
RKO.C
pH 7.5, 12 Gy
pH 6.6, 12 Gy
(h) $\begin{array}{lllllll} & 4 & 8 & 16 & 24 & 48 & 72\end{array}$
C $4 \quad 8 \quad 1624 \quad 48 \quad 72$
Histone H1

\section{$\mathrm{RC} 10.1$ \\ pH 7.5, 12 Gy \\ (h) C $\begin{array}{llllllll}4 & 8 & 16 & 24 & 48 & 72\end{array}$ \\ pH 6.6, 12 Gy \\ $\begin{array}{lllllll}C & 4 & 8 & 16 & 24 & 48 & 72\end{array}$ \\ Histone H1}

B

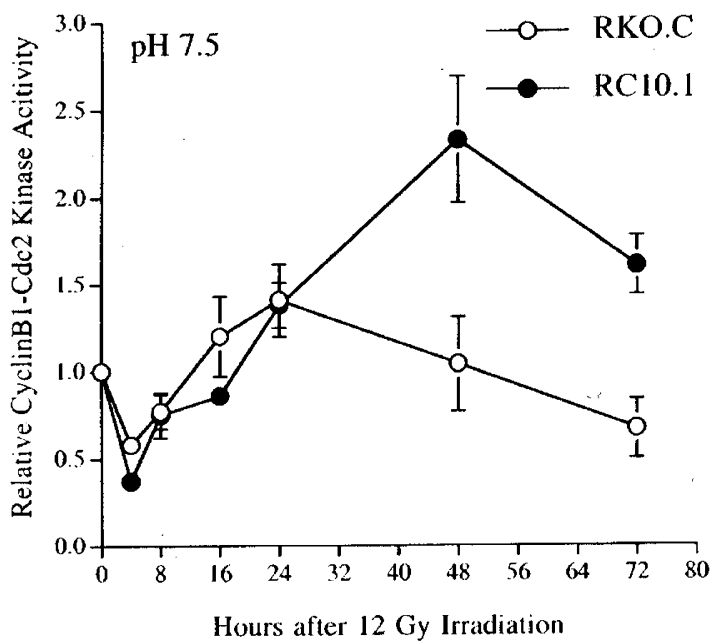

C

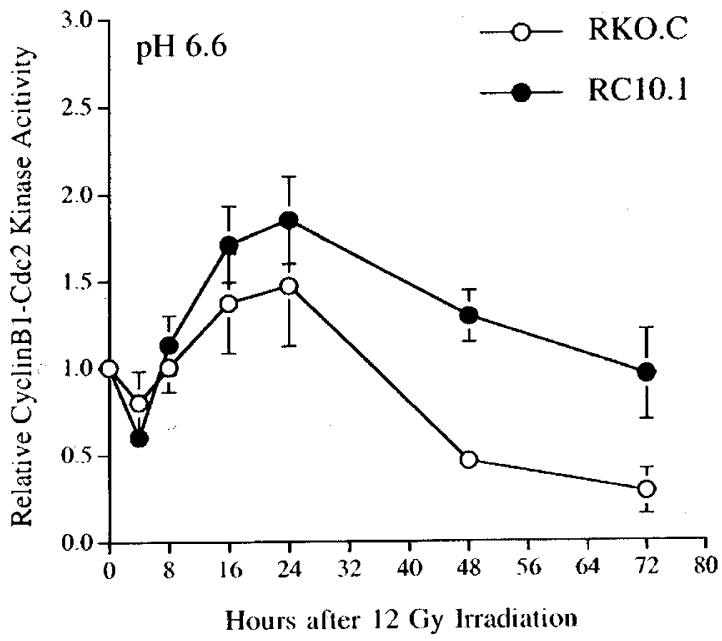

Figure 9 (A) Cyclin B1-associated Cdc2 kinase activity in RKO.C and RC10.1 cells after 12 Gy irradiation in pH 7.5 medium or pH 6.6 medium. Cyclin B1 immunoprecipitates were prepared at different times after irradiation and reacted with $50 \mu \mathrm{g} / \mathrm{ml}$ histone $\mathrm{H} 1,30 \mu \mathrm{M} \mathrm{ATP}$, and $20 \mu \mathrm{Ci}\left[\gamma-{ }^{32} \mathrm{P}\right] \mathrm{ATP}$ at $30^{\circ} \mathrm{C}$ for $30 \mathrm{~min}$ as described in the 'Materials and Methods'. (B) and (C) Relative cyclin B1-associated Cdc2 kinase activity are expressed as the fold of unirradiated control: $O$, RKO.C cells;, $\mathrm{RC} 10 \cdot 1$ cells. The kinase activity was quantitated by liquid scintillation of excised gel fragments. An average of three experiments with $1 \mathrm{~S}$.E. are shown

p53 on radiation-induced apoptosis was greater for the mouse embryonic fibroblasts (MEFs) than that in the human colorectal cancer cells (RKO.C and RC10.1).

In agreement with the results of the flow cytometry study that the increase in the sub-G1 population, i.e. apoptotic cells, was faster in p53-positive cells relative to that in p53negative cells, other indications of apoptosis such as PARP cleavage and DNA fragmentation were significantly greater in RKO.C cells than in RC10.1 cells at $48 \mathrm{~h}$ after 12 Gy irradiation in $\mathrm{pH} 7.5$ medium (Figure 7).

The results obtained in our present studies are in good agreement with reports by others that p53 accelerated the exit of cells from radiation-induced G2/M arrest and that p53 increased or accelerated apoptosis after DNA damage. ${ }^{15,25,28,30-33,36-38}$ In apparent contradiction to these reports, Bunz et $a^{29}$ reported that radiation-induced G2 arrest could be sustained only when p53 was present and that after disruption of either p53 or p21 genes, irradiated cells progressed into mitosis in various human cell lines. Our study indicated that irradiation caused G2 arrest in both p53-positive RKO.C cells and p53-negative RC10.1 cells (Figure 6), and that p53 appeared to accelerate the exit of cells from radiation-induced G2 arrest because the radiation-induced G2/M arrest decayed faster in RKO.C cells than RC10.1 cells (Figures $1-3$ ).

Figure 9 shows that in $\mathrm{pH} 7.5$ medium, the cyclin $\mathrm{B} 1$ Cdc2 kinase activity in both RKO.C cells and RC10.1 cells declined initially and then recovered by $24-48 \mathrm{~h}$ after irradiation. The initial decline in the kinase activity may account for the G2/M arrest after irradiation. The cyclin B1- 
Cdc2 kinase activity in RKO.C cells again declined $72 \mathrm{~h}$ after irradiation in $\mathrm{pH} 7.5$ medium and coincided with the exit of cells from G2/M-phase (Figures 1 and 2), whereas the kinase activity in $\mathrm{RC} 10.1$ cells remained elevated $48-$ $72 \mathrm{~h}$ after irradiation in $\mathrm{pH} 7.5$ medium probably because a large fraction of $\mathrm{RC} 10.1$ cells was still in $\mathrm{G} 2$ phase. Our observations are in agreement with the report by Lock and Ross $^{39}$ that cyclin B1-Cdc2 kinase activity remained upregulated until the cells exited from G2 phase and began mitosis.

Our results unequivocally demonstrate that environmental $\mathrm{pH}$ exerts profound influence on the transition of cells through G2/M-phases. As shown in Figure 1 and Table 1, both RKO.C cells and RC10.1 cells exited from radiationinduced G2/M arrest at a much slower rate in $\mathrm{pH} 6.6$ medium than in $\mathrm{pH} 7.5$ medium. As a consequence, the rate of increase in the apoptotic cell population in $\mathrm{pH} 6.6$ medium was much slower than that in $\mathrm{pH} 7.5$ environment in both cell lines after irradiation (Figures 1 and 3 ). The PARP cleavage and DNA fragmentation were also less in $\mathrm{pH} 6.5$ medium than in $\mathrm{pH} 7.5$ medium. Similar results that acidic environment perturbed the progression of irradiated cells through G2/M-phase thereby suppressing the occurrence of apoptosis were obtained in the study with MEFs (Figure 4). We previously observed that the release from G2/M arrest and subsequent apoptosis were suppressed in an acidic environment in SCK mouse tumor cells carrying mutated $\mathrm{p} 53^{13}$ as well as p53-null HL-60 human leukemia cells. ${ }^{14}$ Such a prolongation of G2/M arrest after irradiation in acidic medium may also be attributed to the prolongation of G2 arrest, as demonstrated by our acridine orange/flow cytometry study (Figure 6).

In both RKO.C cells and RC10.1 cells, the cyclin B1Cdc2 kinase activity in $\mathrm{pH} 6.6$ medium was similar to that in $\mathrm{pH} 7.5$ medium during the first $24 \mathrm{~h}$ after irradiation (Figure 9). However, the kinase activity abruptly decreased following the recovery at $24 \mathrm{~h}$ after irradiation in $\mathrm{pH} 6.6$ medium so that during $48-72 \mathrm{~h}$ after irradiation the kinase activity in the cells in $\mathrm{pH} 6.6$ medium was significantly lower than that in the cells in $\mathrm{pH} 7.5$ medium in both RKO.C cells and RC10.1 cells. Why the kinase activity is decreased after irradiation in $\mathrm{pH} 6.6$ medium and whether this decline in kinase activity in $\mathrm{pH} 6.6$ medium is the cause of the sluggish exit of cells from $\mathrm{G} 2$ arrest in $\mathrm{pH} 6.6$ medium after irradiation remains to be investigated. It also remains to be elucidated whether the decline in cyclin B1-Cd2 kinase activity resulted from a decline in cyclin B1 or phosphorylation of Cdc2.

Depending on the medium $\mathrm{pH}$, there was a subtle difference in the kinetics of change in p53 level after irradiation (Figure 8 ). The radiation-induced increase in p53 levels peaked at $4 \mathrm{~h}$ in $\mathrm{pH} 7.5$ medium and at $8 \mathrm{~h}$ in $\mathrm{pH} 6.6$ medium. Unlike the small difference in the expression of p53 in RKO.C cells after irradiation in the different $\mathrm{pH}$ media, the expression of p21 after irradiation was markedly less in $\mathrm{pH} 6.6$ medium than in $\mathrm{pH} 7.5$ medium, which suggests that acidic stress may suppress the ability of p53 to transcriptionally upregulate $\mathrm{p} 21$.

It is believed that G2 arrest after irradiation allows the cells to repair DNA damage. Whether the prolonged G2 arrest after irradiation in the cells deficient in p53 relative to that in the cells carrying p53 and the prolonged G2 arrest in $\mathrm{pH} 6.6$ medium relative to that in $\mathrm{pH} 7.5$ medium ultimately result in higher clonogenic tumor cell survival remains to be determined. Pertinent to this question is a report that an acidic environment renders cells resistant to radiationinduced clonogenic cell death. ${ }^{12}$ An acidic environment lowers the intracellular $\mathrm{pH}$, although there are a number of cellular mechanisms which prevent drastic changes in the intracellular $\mathrm{pH}^{40}$ Mechanisms by which acidic extracellular environment causes apoptosis and alters the radiation response of cells are being investigated in our laboratory. ${ }^{11,13,14,41}$

\section{Materials and Methods}

\section{Cell line and culture conditions}

RKO.C human colorectal cancer cells carrying wild-type p53 and RC10.1 cells, a subline of RKO.C cells transfected with human papillomavirus type 16 E6 (obtained from Dr. MB Kastan, Johns Hopkins University, Baltimore, MD, USA) were used. We also used

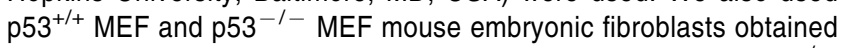
from Dr. AJ Giaccia, Stanford University, Palo Alto, CA, USA). p53 ${ }^{-1-}$ MEFs were obtained by transfecting $153^{+/+}$MEFs with adenovirus early region $I A(E 1 A)$ and $H$-ras oncogen. The cells were grown in DMEM supplemented with $10 \%$ fetal bovine serum and $1 \%$ penicillin/ streptomycin. The cells were cultured in $25 \mathrm{~cm}^{2}$ plastic tissue culture flasks at $37^{\circ} \mathrm{C}$ in a humidified $5 \% \mathrm{CO}_{2} / 95 \%$ air atmosphere. When the cells were in exponential growth phase at a cell density of $3 \times 10^{6}$ cells/ $25 \mathrm{~cm}^{2}$ flasks, the media was replaced with fresh media that had been adjusted to the desired $\mathrm{pH}$ value using $30 \mathrm{mM}$ each of Tris, MOPS (3(4-morpholino) propanesulfonic acid) and MES (morpholinoethanesulfonic acid) buffers.

\section{Irradiation of cell cultures}

After the cells were conditioned to the new $\mathrm{pH}$ media for $30 \mathrm{~min}$ at $37^{\circ} \mathrm{C}$, they were irradiated with 4 Gy or 12 Gy of $\gamma$-rays at a dose rate of $0.9 \mathrm{~Gy} / \mathrm{min}$ with a ${ }^{137} \mathrm{Cs}$ irradiator.

\section{DNA gel electrophoresis}

After the various treatments, the cells were collected, washed with PBS, and resuspended in lysis buffer $(10 \mathrm{mM}$ Tris- $\mathrm{HCl}, \mathrm{pH} 7.4 ; 10 \mathrm{mM}$ $\mathrm{NaCl} ; 10 \mathrm{mM}$ EDTA; proteinase $\mathrm{K}$ at $0.1 \mathrm{mg} / \mathrm{ml} ; 1 \%$ (w/v) SDS) and incubated at $48^{\circ} \mathrm{C}$ overnight. Cold $\left(4^{\circ} \mathrm{C}\right) 5 \mathrm{M} \mathrm{NaCl}$ solution was then added to the lysate, the mixture was vortexed for several seconds, and then centrifuged at $10000 \times g$ for $5 \mathrm{~min}$. The supernatant was mixed with isopropanol $(1: 1)$ and incubated at $-20^{\circ} \mathrm{C}$ overnight to precipitate the DNA. After centrifuging at $12000 \times g$ for $20 \mathrm{~min}$, the pellet was resuspended in TE buffer $(10 \mathrm{mM}$ Tris- $\mathrm{HCl} \mathrm{pH} \mathrm{7.4,1} \mathrm{mM}$ EDTA) and the RNA was digested by adding $0.2 \mathrm{mg} / \mathrm{ml}$ DNase-free RNase. An aliquot of $15-20 \mu \mathrm{g}$ of DNA from each sample and the DNA molecular weight marker were subjected to electrophoresis on $1.5 \%$ agarose gel in TBE ( $89 \mathrm{mM}$ Tris base, $89 \mathrm{mM}$ boric acid, $2 \mathrm{mM}$ EDTA) and the DNA was stained with ethidium bromide. ${ }^{6,11}$

\section{Western blot analysis}

Cell lysates were prepared with solubilizing buffer $(\mathrm{pH} 7.4,1 \%$ Triton $\mathrm{X}-100,1 \%$ deoxycholic acid sodium salt, $0.1 \%$ SDS, $20 \mathrm{mM}$ Tris- $\mathrm{HCl}$, 
$150 \mathrm{mM} \mathrm{NaCl}, 5 \mathrm{mM}$ EDTA, $2 \mathrm{mM}$ PMSF, $2 \mu \mathrm{g} / \mathrm{ml}$ aprotinin and $2 \mu \mathrm{g} /$ $\mathrm{ml}$ leupeptin). Cell lysates were analyzed by $7.5 \%$ polyacrylamide gel. After SDS-PAGE was performed, proteins were transferred to a PVDF membrane (Amersham, Piscataway, NJ, USA). The membrane was blocked with Tris-buffered saline supplemented with $0.05 \%$ Tween-20 (TBST) including $3 \%$ milk at $4{ }^{\circ} \mathrm{C}$ overnight. The membrane was then incubated with anti-PARP antibody (1:500; Upstate Biotechnology, Lake Placid, NY, USA), anti-p53 (1 $\mu \mathrm{g} / \mathrm{ml}$; Oncogene Research Products, Cambridge, MA, USA), anti-p21 ( $1 \mu \mathrm{g} / \mathrm{ml}$; Upstate Biotechnology, Lake Placid, NY, USA), and anti- $\beta$ Tubulin $(1 \mu \mathrm{g} / \mathrm{ml}$; PharMingen, San Diego, CA, USA), and secondarily incubated with a HRP-conjugated antibody (1:2000, Amersham, Piscataway, NJ, USA). Subsequently, the membrane was developed with $E C L$ Western blotting detection reagents according to the manufacturer's instructions. ${ }^{6,11}$

\section{Flow cytometric analysis}

$P I$ method $^{13}$ Cells were fixed in $10 \mathrm{ml}$ cold $80 \%(\mathrm{v} / \mathrm{v})$ ethanol at $4^{\circ} \mathrm{C}$ overnight. The cells were then centrifuged, washed with $1 \mathrm{ml} P B S$ and resuspended in $2 \mathrm{ml}$ PBS. To a $2 \mathrm{ml}$ cell suspension, 30 units of DNasefree RNase was added and then $100 \mathrm{ml} \mathrm{PI} \mathrm{(propidium} \mathrm{iodide;} 50 \mu \mathrm{g} / \mathrm{ml}$ ) was added. After a gentle mixing, the resuspended cells were incubated in the dark at $37^{\circ} \mathrm{C}$ for $1 \mathrm{~h}$ and covered until used. The fluorescence of the cells was measured using about $2 \times 10^{4}$ cells in a FACSCalibur flow cytometer (Becton Dickinson, San Jose, CA, USA). The fraction of cells in each cell cycle stage or undergoing apoptosis was estimated from the cellular DNA content. 6,11

Acridine orange method ${ }^{34}$ Cells were trypsinized, rinsed in PBS and fixed in $80 \%(\mathrm{v} / \mathrm{v})$ ethanol at $4^{\circ} \mathrm{C}$ overnight. The cells were then centrifuged, resuspended in $1 \mathrm{ml}$ PBS containing $10 \mu \mathrm{g} / \mathrm{ml}$ DNAse-free RNAse $\mathrm{A}$ and incubated at $37^{\circ} \mathrm{C}$ for $1 \mathrm{~h}$. After centrifugation, the cells were resuspended in $0.1 \mathrm{M} \mathrm{HCL}$ and left at room temperature for $30 \mathrm{~s}$ to denature the DNA. $0.5 \mathrm{ml}$ acridine orange was added to the sample, and then the cell sample was run through a flow cytometer. The forward and side scatter thresholds and the red fluorescence gate were set to exclude cells that were clearly apoptotic so that only data from non-apoptotic cells was collected. The data from $2 \times 10^{4}$ cells were collected from each sample and the green fluorescence was plotted against the red fluorescence. It was possible to clearly discern G1, S, G2 and mitotic cells using this type of bivariate analysis.

\section{Cyclin B1-associated Cdc2 kinase activity}

Cells $\left(3 \times 10^{6} /\right.$ sample) were lysed in $500 \mu$ l of $1 \% \mathrm{NP}-40$ buffer $(\mathrm{pH}$ $7.4,1 \% \mathrm{NP}-40,0.25 \%$ deoxycholic acid sodium salt, $0.1 \%$ SDS, $20 \mathrm{mM}$ Tris- $\mathrm{HCl}, 150 \mathrm{mM} \mathrm{NaCl}, 1 \mathrm{mM}$ EDTA, $1 \mathrm{mM}$ sodium orthovanadate, $1 \mathrm{mM}$ sodium fluoride, $2 \mathrm{mM}$ PMSF, $10 \mathrm{mM}$ iodoacetamide, $1 \mu \mathrm{g} / \mathrm{ml}$ aprotinin and $1 \mu \mathrm{g} / \mathrm{ml}$ leupeptin). Lysates were spun twice at $12000 \times g$ for $15 \mathrm{~min}$ at $4^{\circ} \mathrm{C}$ and immunoprecipitated using mouse monoclonal anticyclin B1 antibody $(100 \mu \mathrm{g}$ lysates, $1 \mu \mathrm{g}$ antibody; Santa Cruz Biotechnology, Santa Cruz, CA, USA) for $2 \mathrm{~h}$. Immune complexes were collected with $50 \mu$ of protein A-sepharose beads (Repligen, Cambridge, MA, USA), washed four times with $1 \%$ NP-40 buffer and then equilibrated in kinase buffer (50 mM Tris-Cl, pH 7.4, $10 \mathrm{mM} \mathrm{MgCl}$, $1 \mathrm{mM}$ DTT). Samples were incubated with $50 \mu \mathrm{g} / \mathrm{ml}$ histone $\mathrm{H} 1$ (Boehringer-Mannheim, Indianapolis, IN, USA), $30 \mu \mathrm{M}$ ATP, and $20 \mu \mathrm{Ci}\left[\gamma^{32}\right.$ P]ATP (ICN, Costa Mesa, CA, USA) at $30^{\circ} \mathrm{C}$ for $30 \mathrm{~min}$. The kinase reactions were terminated by the addition of an equal volume of $2 \times$ SDS-sample buffer. The reaction mixture were resolved on $12 \%$ SDS-polyacrylamide gels. Kinase activity was visualized by autoradiography and quantitated by $\beta$ counter. $^{31}$

\section{Acknowledgements}

The authors are thankful to Dr. Seymour H Levitt for his continuous encouragement and Ms. Peggy T Stewart for her editorial assistance. This work was supported by a National Cancer Institute grant (CA13353) and KOSEF-1999-2-208-003-3.

\section{References}

1. Gullino PM (1975) Extracellular compartments of solid tumors. In Biology of tumors: cellular biology and growth, BeckerFF, ed (New York: Plenum Press) pp. $327-354$

2. Wike-Hooley JL, Haveman J and Reinhold HS (1984) The relevance of tumour $\mathrm{pH}$ to the treatment of malignant disease. Radiother. Oncol. 2: 344-366

3. Vaupel $P$, Kallinowski F and Okunieff $P$ (1989) Blood flow, oxygen and nutrient supply and metabolic microenvironment of human tumours: a review. Cancer Res. 49: 6449-6465

4. Song CW, ParkHJ and Ross BD (1999) Intra-and extracellularpH in solid tumors. In Antiangiogenic Agents in Cancer Therapy, Teicher BA, ed (New Jersey: Humana Press) pp. 51-64

5. Barry MA and Eastman A (1993) Identification of deoxyribose II as an endonuclease involved in apoptosis. Arch. Biochem. Biophysics 300: 440-450

6. Park HJ, Makepeace CM, Lyons JC and Song CW (1996) Effect of intracellular acidity and ionomycin on apoptosis in HL-60 cells. Europ. J. Cancer 32A: $540-$ 546

7. Jähde E, Glusenkamp KH, Klunder I, Hulser DF, Tietze LF and Rajewsky MF (1989) Hydrogen ion-mediated enhancement of cytotoxicity of bis-chlorethylating drug in rat mammary carcinoma cells in vitro. Cancer Res. 49: 2965-2972

8 Song CW, Lyons JC and Luo Y (1993) Intra- and extracellular pH in solid tumors: Influence on therapeutic response. In Drug Resistance in Oncology, Teicher B, ed (New York: Marcel Dekker) pp. 25-51

9. Chu G and Dewey WC (1988) The role of low intracellular or extracellular pH in sensitization to hyperthermia. Radiat. Res. 114: 154-167

10. Song CW, Lyons JC, Griffin RJ, Makepeace CM and Crago Jr. EJ (1993) Increase in thermosensitivity of tumor cells by lowering intracellular $\mathrm{pH}$. Cancer Res. 53: 1599-1601

11. Takasu T, Lyons JC, Park HJ and Song CW (1998) Apoptosis and perturbation of cell cycle progression in acidic environment after hyperthermia. Cancer Res. 58: 2504-2508

12. Freeman ML, Holahan EV, Highfield DP, Raaphorst $P$, Spiro IJ and Dewey WC (1981) The effect of pH on hyperthermic and X-ray induced cell killing. Int. J. Radiat. Oncol. Biol. Phys. 7: 211-216

13. Lee HS, Park HJ, Lyons JC, Griffin RJ, AugerEA and Song CW (1997) Radiationinduced apoptosis in different $\mathrm{pH}$ environments in vitro. Int. J. Radiat. Oncol. Biol. Phys. 38: 1079-1087

14. Park HJ, Lyons JC, Ohtsubo T and Song CW (1999) Acidic environment causes apoptosis by increasing caspase activity. Br. J. Cancer 80: 1892-1897

15. Peled A, Schwartz D, Elkind NB, Wolkowicz R, Li R and Rotter V (1996) The role of $p 53$ in the induction of polyploidity of myelomonocytic leukemic M1/2 cells. Oncogene 13: 1677-1685

16. Kastan MB, Onyekwere O, Sidransky P, Vogelstein B and Craig RW (1991) Participation of $p 53$ protein in the cellular response to DNA damage. CancerRes. 51: $6304-6311$

17. Levine AJ (1997) p53, the cellular gatekeeper for growth and division. Cell 88: $323-331$

18. O'Connor PM, Jackman J, Bae I, Myers TG, Fan S, Mutoh M, Scudiero DA, Monks A, Saasville FS, Weinstein JN, Friend S, Fornace AJ and Kohn KW (1997) Characterization of the p53tumor suppressor pathway in cell lines of the National Cancer Institute Anticancer Drug Screen and correlations with the growthinhibitory potency of 123 anticancer agents. Cancer Res. 57: 4285-4300 
19. Nagasawa H, Li C-Y, Maki CG, Imrich AC and Little JB (1995) Relationship between radiation-induced $G_{1}$ phase and p53 function in human tumor cells. Cancer Res. 55: 1842-1846

20. Nagasawa $H$, Keng $P$, Maki C, Yu T and Little JB (1998) Absence of a radiationinduced first-cycle $\mathrm{G}_{1}-\mathrm{S}$ arrest in $\mathrm{p} 53^{+}$human tumor cells synchronized by mitotic selection. Cancer Res. 58: 2036-2041

21. Little JB, Nagasawa H, Keng PC, Yu Y and Li C-Y (1995) Absence of radiationinduced $\mathrm{G} 1$ arrest in two closely related human lymphoblast cell lines that differ in p53 status. J. Biol. Chemistry 270: 11033-11036

22. Li C-Y, Nagasawa H, Dahlbert WK and Little JB (1995) Diminished capacity for p53 in mediating a radiation-induced $G_{1}$ arrest in established human tumor cell lines. Oncogene 11: 1885-1892

23. Kaufman WK, Levedakou EN, Grady HL, Paules RS and Stein GH (1995) Attenuation of G2 checkpoint function precedes human cell immortalization. Cancer Res. 55: 7-11

24. Hwang A and Müschel RJ (1998) Radiation and the G2 phase of the cell cycle. Radiat. Res. 150: S52-S59

25. Strasser-Wozak EMC, Hartmann BL, Geley S, Sgonc R, Böck G, Dos Santos AJO, Hattmannstorfer R, Wolf H, Pavelka M and Kofler R (1998) Irradiation induces G2/M cell cycle arrest and apoptosis in p53-deficient lymphoblastic leukemia cells without affecting Bcl-2 and Bax expression. Cell Death Differ. 5: $687-693$

26. Stewart N, Hicks GG, Paraskevas F and Mowat M (1995) Evidence for a second cell cycle block at G2/M by p53. Oncogene 10: 109-115

27. Agarwal ML, Garwal A, Taylor WR and Stark GR (1995) p53 controls both the G2/ $\mathrm{M}$ and the $\mathrm{G} 1$ cell cycle checkpoints and mediates reversible growth arrest in human fibroblasts. Proc. Natl. Acad. Sci. USA 92: 8493-8497

28. SchwartzD, Almog N, Peled A, GoldfingerNand Rotter V (1997)Role of wild-type p53 in the G2 phase: regulation of the $\gamma$-irradiation-induced delay and DNA repair. Oncogene 15: 2597-2607

29. Bunz F, Dutriaux A, Lengauer C, Waldman T, Zhou S, Brown JP, Sedivy JM, Kinzler KW and Vogelstein B (1998) Requirement for p53 and p21 to sustain G2 arrest after DNA damage. Science 282: 1497-1501

30. Guilloud C, Rosselli F, Krishnaraju K, Moustacchi E, Hoffman B and Liebermann DA (1995) p53 involvement in control of G2 exit of the cell cycle: role in DNA damage-induced apoptosis. Oncogene 10: 2263-2270
31. Leach SD, Scatena CD, Keefer CJ, Goodman HA, Song HY, Yang L and Pietenpol JA (1998) Negative regulation of Wee1 expression and Cdc2 phosphorylation during p53-mediated growth arrest and apoptosis. Cancer Res. 58: $3231-3236$

32. Bracey TS, Miller JC, Preece A and Paraskeva C (1995) Gamma-radiationinduced apoptosis in human colorectal adenoma and carcinoma cell lines can occur in the absence of wild-type p53. Oncogene 10: 2391-2396

33. GoiK, Takagi M, Iwata S, Dlia D, Asada M, Donhi R, Tsunematsu Y, Nakazawa S, Yamamoto H, Tokota J, Tamura K, Saeki Y, Utsunomiya J, Takahashi T, Ueda R, Ishioka C, Eguchi M, Kamata N and Mizutani S (1997) DNA damage-associated dysregulation of the cell cycle and apoptosis control in cells with germ-line p53 mutation. Cancer Res. 57: 1895-1902

34. Darzynkiewicz Z (1994) Acid-induced denaturation of DNA in situ as a probe of chromatin structure. In Methods in Cell Biology, Vol 41, Darzynkiewicz Z, Robinson JP, Crissman HA, eds. (San Diego: Academic Press) pp. 527-541

35. Green DR (1999) Apoptotic pathway: The roads to ruin. Cell 94: 695-698

36. Yu Y and Little JB (1998) p53 is involved in but not required for ionizing radiationinduced caspase-3 activation and apoptosis in human lymphoblast cell lines. Cancer Res. 55: 4277-4281

37. Xia R, Wang X, Wang Y-H, Tsang N-M, Yandell DW, Kelsey KT and Liber HL (1995) Altered p53 status correlates with differences in sensitivity to radiationinduced mutation and apoptosis in two closely related human lymphoblast lines. Cancer Res. 55: 12-15

38. Held KD (1997) Radiation-induced apoptosis and its relationship to loss of clonogenic survival. Apoptosis 2: 265-282

39. Lock RB and Ross WE (1990) Inhibition of $\mathrm{p} 34^{\mathrm{cdc} 2}$ kinase activity by etoposide or irradiation as a mechanism of $\mathrm{G} 2$ arrest in Chinese hamster ovary cells. Cancer Res. 50: $3761-3766$

40. Song CW, Lyons JC, Luo Y (1993) Intra- and extracellular pH in solid tumors: Influence on therapeutic response. In Drug Resistance in Oncology, Teicher B, ed. (New York: Marcel Dekker, Inc.) pp.25-51

41. Park HJ, Makepeace CM, Lyons JC, Song CW (1996) Effect of intracellular acidity and ionomycin on apoptosis in HL-60 cells. Europ. J. Cancer 32A: 540 546 